\title{
Social Capital in Achieving the Success of the Election of Mayors and Deputyof Palangka Raya
}

\author{
Muhammad Hasan Busyairi ${ }^{1}$, Ishomuddin ${ }^{2 *}$, RahayuHartini ${ }^{3}$, Rinikso Kartono ${ }^{4}$ \\ ${ }^{1}$ Doctor Candidate of Social and Political Sciences of University of Muhammadiyah Malang \\ ${ }^{2}$ Professor of Sociology of Islamic Society of University of Muhammadiyah Malang, \\ ${ }^{3}$ Professor of Commercial Law and Bankruptcyof University of Muhammadiyah Malang \\ ${ }^{4}$ Doctor of Social Welfare of University of Muhammadiyah Malang
}

*Corresponding Author: Ishomuddin, Professor of Sociology of Islamic Society of University ofMuhammadiyah Malang

\begin{abstract}
This study aims to analyze what social capital candidates use in achieving success in the election for Mayor and Deputy Mayor of Palangka Raya.Thisresearchemployed a qualitative approachbycarried out in a naturalistic manner.The subject of this research involves the candidates for mayor and deputy mayor, political party administrators, community leaders, religious leaders, traditional leaders, cultural figures, youth leaders, government officials, and also the people of Palangka Raya. The data collection technique is done through observation, interview and documentation.In addition, In order for the data obtained to be more accurate, observations were made diligently, triangulated and discussed with all informants, then the data obtained were analyzed following the qualitative research procedures proposed by Creswell with stages starting from (1) processing and preparing the data for analysis, (2) reading the whole data, (3) analyze in more detail by coding the data, (4) apply the coding process to describe the setting, (5) show how these descriptions and themes will be presented again in the narrative / research report, and (6) interpret the data. The theory used to explain in this research is social capital theory.The results of this study indicatethat basically the social capital used by candidate pairs to achieve success in winning the Election of Mayor and Deputy Mayor of Palangka Raya,and also in receiving full support from the power of political parties, cultural figures, religious leaders, youth leaders.An interesting finding in this research is the support of a supernatural group consisting of shamans and charismatic kiyai (Priest).
\end{abstract}

Key words: Social Capital, Winning Strategy, Mayor Election

\section{INTRODUCTION}

Before becoming a regional head, the prospective registrants must participate in the contest ofRegional Head elections (Pilkada). He must have broad social capital support in the community, without strong support, it will be impossible for him to win regional head elections. He must have broad social capital support in the community, without strong support, it will be impossible for him to win the regional head elections.

Pilkada is a political moment that involves all elements and social instruments in society. According to Putnam (1993); Fukuyama (1995) states that social capital is a social institution that involves a network, norms and beliefs in the community that continues and develops in the community Thus, it grows into a common interest.The formation of a broad network that is already owned by a candidate, it can be developed in making a mapping and understanding of field conditions, which are interpreted as the contemporary socio-political conditions of the people in Palangka Raya.

The Candidates should beunderstanding the characteristics of the voter behavior, for instance, the understanding of voter tendencies towards money politics, loyalty to parties, education level and economic background, ethnic sentiment, and religion. In general, the socio-political map of society that must be understood by candidates.In normal social relations, it is only natural that the candidates for mayor and deputy mayor have a strong interest in using the elite as a political machine which is expected to work effectively to gather votes at the grass root level. On the other hand, the elitealso have reasons for their own interests to be achieved from theirrelationships. 
According to the relationship between the two actors, it seems that there is an exchange of resources. Therefore, the outcome of the expected result is a mutually beneficial relationship. It can be concluded that the triggers for the formation of a network are information and interests. In the context of the elections, each region has different characteristics, it starting from the political structure, economic structure and social structure. In a society with very strong primordial ties, social relations that adhere to the principle of "patron-client" cannot be avoided. Relationship patterns do not only occur in formal structures but also occur in informal structures, such as in social organizations such as social organizations, religious organizations and so on formed by formal rules, but the social relationships that exist between them create a gap for the development of patron relationships-clients both among the members and the levels of the social organization.

In addition, candidates for mayor and deputy mayor also need to pay attention to political maps which are accurate information tools that provide a clear picture of direct candidates, competitors, society, communication media and various other important issues. This political map means a must-have for the Mayor and Deputy Mayor candidates, the political map will be a reference for the Mayor and Deputy Mayor candidates in choosing the most appropriate path to achieve their goals. Thus, with this political map, the candidates for Mayor and Deputy Mayor will know the weaknesses and strengths of themselves and their competitors, and also will not be fooled by various misleading information. Candidates for Mayor and Deputy Mayor can still focus on the targets and targets that must be pursued.

The social network map concerns the existence of social, religious, youth, kinship and bureaucratic organizations that are influential in the region. This network mapping is very useful for candidates to build an effective mobilization engine. By knowing the map of influential social networks, candidates can determine what social ties or organizations can be used as vote mobilizing engines. An influential social organization here can be defined as an organization that has a large or broad number of members.A candidate cannot ignore the existence of an influential social organization as an organization that can be a reference for voters. In addition, candidates must communicate and have a close relationship with ulama and community leaders to get some kind of blessing to win Regional Head Elections (Pilkada).

The voter behavior map is about the behavior, attitudes and opinions of the people in this area. By mapping the political behavior of voters, candidates can also find out in detail how the political behavior of the community, including public opinion about the candidate and his competitors.

This voter behavior map will reveal differences in voter behavior by region, social segment, education level, economic level, community organization affiliation, and so on. For example, candidates will know exactly how the opinions and attitudes of farmer groups, women, youth, Party cadres and other groups towards the candidate's image and certain political issues. With this voter behavior map candidates can determine specific strategic steps based on certain areas and social segments. Another important thing from mapping voter behavior is that candidates can know what the public wants of the candidate's image. For example, if the community wants a mayor who is young and independent, progressive, the candidate can carry out his own image according to the wishes of the community.

The communication media map is related to the communication media data that most effectively affects the community in the region. The communication media referred to anything that involves all types and forms of communication media. Starting from outdoor media (banners, billboards, posters and so on), souvenirs, printed media, radio, television, face to face, mobile phones, internet, multimedia, to traditional communication media (such as Manasai). In fact, candidates do not need to use all existing communication media if in an area not all communication media can be used.

The impact of the presence of this communication media map for candidates is that they can determine what communication media should be used and who are the targets. This is important, because each media has different characteristics. For example, the characteristics of outdoor media such as billboards, banners and posters have the advantage of influencing voters' cognition or increasing popularity (level of popularity).

Trust capital is no less important than other social capital. Attitudes and behavior of candidates are the main points in attracting public sympathy and support. The candidates should be able to grow their image and charisma. A friendly attitude, polite, modest, humble, helpful, and can provide a sense of 
comfort will foster a strong trust from the community. When this trust is able to be nurtured, the community will automatically be awake and imprinted in their hearts on these candidates so that on election day they will always be remembered and elected by the public.

Another factor prior to the local head election that candidates should pay attention to attract the public interest of the Dayak community. They are still believing in the spirits of their ancestors. Moreover, they usually communicate with the ancestral spirits through the Sangiang rituals (the chosen people who are able to communicate with ancestral spirits). This becomes the basis for every regional election for "Sons of the Soil" (Putra Daerah) before they are deciding to compete in the regional elections, they ask permission and blessing from the spirits of their deceased ancestors.

In addition, they asked for prayers and blessings from the great local ulama, then, they also asked for opinions from Orang Pintar (Shaman), who are considered capable of seeing and reading the process of events in the future.In Addition, this shaman is also considered capable of providing information to humans about events in the universe and other unseen incidents,Syamsudin (2008).

In fact, apart from the Orang Pintar's(shaman) function, apart from providing information about what events will happen, they are also used as companions and even political advisers until the election is over.This is done as a belief that is still believed by some candidates by carrying out ritual events guided by a traditional leader.

\section{THEORITICAL FRAMEWORK}

Pierre Bourdieu (1986), in his book The Forms of Capital distinguishes three forms of capitalnamely, economic capital, cultural capital and social capital. He said that the capital is very broad and includes material things that can have symbolic value, as well as cultural capital which is defined as tastes with cultural values and consumption patterns.Cultural capital encompasses a wide range of property, such as art, education, and forms of language.

For Bourdieu, capital acts as a social relation contained in a system of exchange, and this term is extended to all forms of goods, both material and symbolic, without distinction which presents itself as something that is rare and worthy of being sought in a particular social formation.Capital must exist in a domain, therefore that domain can have meaning.

However, it can also be explained at another level using the generative formula. An explanation like this is a bit artificial but useful. The relationship between domain, habitus, and capital is direct. The value given by capital is associated with the various social and cultural characteristics of the habitus. The domain is surrounded by objective power relations which have a material basis. The types of capital which are recognized in certain domains and which are incorporated into the habitus are partly generated by this material basis.

Bourdieu also sees Capital as the basis of domination. Various types of capital can be exchanged with other types of capital, which means that capital is exchangeable. The greatest exchange that has been made is exchange for symbolic capital, because it is in this form that different capital is perceived and recognized as legitimate.

Moreover, in order to be viewed as a person or class with status and prestige, it means that he must be accepted as something legitimate. For instance, a position carries the power to name (group activity), which represents public opinion and the main in which power creates an official version of the social world.

The theory of social capital put forward by Bourdieu is further continued by Putnam and Fukuyama that "the resources owned by a person or group of people by utilizing a network or relationship that are institutionalized, and there is a mutually acknowledging relationship between its members".

\section{METHODOLOGY}

In accordance with the characteristics of the people in the city of Palangka Raya, this research was conducted using qualitative methods. The qualitative method can be used to reveal and understand something behind a phenomenon that is not even the least bit known(Strauss and Corbin, 2017: 5). Qualitative research is methods to explore and understand meaning - by a number of individuals or groups of people - ascribed to social or humanitarian problems (Creswell, 2017: 4). 
The research subjects used as key informants were the candidates for the Regional Election itself, party administrators, successful team, community leaders, religious leaders, traditional leaders, cultural figures, youth and community leaders in Palangka Raya, with data collection techniques through observation, interviews and documentation. While data analysis was carried out following qualitative research procedures proposed by Miles, Huberman and Saldana, (2014: 8-10), it is starting from (1) condensation data (data condensation), (2) data display, and (3), describe and verify conclusions.

\section{RESUlT AND DisCUSSION}

After the researcher made observations, interviews and documentation of the participants who were willing to provide data and information, the researcher compiled a report and presented the research data as follows:

1.1. There is the influence of strong support regarding social capital for candidates in achieving the success of the election for Mayor and Deputy Mayor of Palangka Raya. Social capital is part of a social network of life, norms and beliefs that encourage participation to act together more effectively to achieve common goals. (Putnam, 2000; Field 2018: 51). The support for social capital in achieving success to win the contestation for the Mayor and Deputy Mayor of Palangka Raya. It is in addition to the important role of figures and motivation for candidates, but it also takes advantage of social support consisting of support from political parties and local authorities, a strong successful team. In addition, the role of community leaders, religious leaders, traditional and cultural leaders, the role of the younger generation and the role of social support from supernatural groups. According to Edward B. Tylor; Richter. Jr. (1987: 146) Culture as "that complex whole which includes knowledge, art, morals, law, custom and any ather capabilities and habits acquired by man as a member of socity".

The population of Palangka Raya involve of various ethnicities and religions thus, it is not surprising that there are many kinds of customs and cultures. Besides, it is being very thick with Dayak customs and culture, there are many other customs and cultures such as Javanese culture, Balinese culture, Bugis culture, Minang culture, Batak culture, Maluku culture, Nusa Tenggara culture and many other customs and cultures of the community. There is still preserved and it well preserved by their respective ethnic groups. In fact, it is natural that they emotionally channel their political choices to candidates who have ethnic and cultural similarities. As David Kaplan and Robert A. Manners (2012: 30) state that the model possessed by citizens of a culture is determined by the position of that citizen in the community.

However, if there is every major celebration such as the Regional election in palangka Raya, the candidates who take part in the political contestation in the election are usually preceded by ritual events, both religious rituals or traditional rituals.Furthermore, the custom that exists in Palangka Raya is that what is conveyed by traditional leaders must be followed by their followers in society, including the supernatural role of shamans and kiyais.

Putnam (1993); Field, (2018: 49) states that... social capital refers to parts of a social organization, such as beliefs, norms and networks, which can increase the efficiency of society by facilitating coordinated actions. The presence of ritual events carried out by the community in order to provide support to prospective contestants following the election for Mayor and Deputy Mayor of Palangka Raya.According to Francis Fukuyama, (2010) that people in traditional culture always follow traditional rules and take actions very different from people in industrialized societies, but because traditional culture contains embedded rules of behavior that are rational for the culture itself.

1.2. If we examine the strategies of the candidates in order to get the most votes therefore that they can win in the contestation following the election for Mayor and Deputy Mayor of Palangka Raya, the results of the research show that what the prospective participants do is:

1.2.1. They are able to create careful planning in the implementation of Regional Election in Palangka Raya, since a strategy for candidates to win the Regional Election. This should be applying to all candidates in compiling their plans, based on researchers' observations of all contestants using the Strength, Weakness, Opportunities, and Threats analysis (SWOT). 
1.2.2. The participants be able to create a reliable campaign team, since the results of the researchers' observations at each candidate winning post, the researcher gets an idea of how the scenario is ready to run during the campaign implementation period. The scenario is that the assigned campaign team is complete, from political strategists, religious leaders, community leaders, cultural and traditional leaders, as well as youth organizations for each candidate.

In the field, it can be seen that the campaign team of each candidate in the Regional Election contest to become Mayor and Deputy of Palangka Raya are generally ready, both from the campaign team, costs and other supporting facilities. This can be seen from the figures and profiles of each candidate, all of whom are well established and both have sufficient and strong financial resources to finance their team during their campaign. In a political campaign, the most significant thing is about the messages the candidates convey. Each of them tried to bring a certain theme or topic to be offered to the community. Some of us may be more familiar with political promises. This could be true, because it is part of the message in a political campaign, although it does not always mean that(Siti Fatimah, 2018: 7).

Based on the results of the researcher's monitoring of these four candidate pairs in terms of the campaign team, in addition to relying on the maximum political party supporting them, they also rely a lot on support outside the team, such as family lines, community leaders, youth leaders, regional ethnic groups and also pathways. supernatural like shamans and the like.

1.2.3. They are able to achieve a vision and mission that touches the needs of the community, sincethe candidates who will take part in the Regional Election as Mayor is required to compile his vision and mission which will be conveyed during the campaign or at the time of the mayor candidate debate.Furthermore, according to Wela Harni and Agung Suprojo (2016: 87) conceptualizing a vision is a picture of the future of an organization or an institution. Defining a vision, it also means determining the goals and aspirations to be achieved. While the mission is anything that can be done to achieve the vision. As already explained, the mission is what steps, methods or strategies to achieve the vision.

While we look at the data on the vision and mission documentation of the candidates along with the informants' verbal explanation.A vision is made and formulated in detail using a political planning expert consultant with the candidates and their successful team. Therefore, it touches the problems that face of the people of Palangka Raya, however there is also a mission that only formulated and elaborated by the candidates together with theirsuccessful team.

1.2.4. They can take advantage of technology, if in the past in regional elections they only met face to face by inviting large audiences in the field and by using radio and newspapers. In the fact, in today's digital era people campaign in addition to meeting the audience, by using newspapers and radio. They even use television, internet technology and other social media. This is due to the quality of the results from the regional election to vote the Mayor and Deputy Mayor, it is depending on the quality of support for the use of good internet communication and information technology. Furthermore, the Internet as a tool also contributes to the formation of new dimensions of culture. In fact, this has a significant influence on the occurrence of social reality. (Rulli Nasrullah, 2018: 19)

1.2.5. They are able to create a positive image and come to the community with a variety of techniques and strategies, some greet the community by providing food assistance to the poor, holding meetings with community leaders for specific reasons or discussing development progress.In addition, there are also attending prayers at the mosque and after the prayer the candidate for mayor asks the congregation to introduce himself that he is a candidate for mayor or deputy mayor in the upcoming regional head elections. Ibrahim (1994: 208) argues that... communicative forms and processes are social structures, values and attitudes about language and ways of speaking, a conceptual category framework that comes from the same practice, and ways of knowledge and skills (including language).

Based on the observations of researchers, from January to June 2018 in terms of various imagery built by the candidates for Mayor and Deputy Mayor of Palangka Raya, there is an image of candidates who are impromptu in nature who previously had never been involved, then now they are suddenly participate in religious groups in such as the recitation group, whether the recitation group for male or female by distributing worship tools and so on, all of these behaviors are 
nothing but building a relationship with the aim of getting recognition and image from the community for themselves.

James S. Coleman in his rational choice theory focuses more on actors, as quoted by Ritzer, (2014: 332) that: Actors are seen as humans who have goals or have goals. This means that the actor has a goal and his actions are aimed at achieving that goal. Actors are seen as having choices (or values, needs). Rational choice theory does not care about what is the choice or what is the source of the actor's choice. What matters is the fact that actions are taken to achieve goals that are at the level of choice of actors. They should be meet and interactwith the community directly, it is much better and more effective in achieving appreciation of the community's image when compared to just relying on the work of a successful team and other volunteers.

\section{CONCLUSION}

In this study, it was found that there was a strong support effect for candidates in achieving successful victories in the election for Mayor and Deputy Mayor of Palangka Raya, and the role of Social capital in achieving success in winning the contestation.

The social capital support that prospective participants have in the election contest are the role of figures and motivation for candidate pairs.

They also take the advantage of social support in the form of political party support as candidate, from local authorities, a strong successful team, community leaders, religious leaders, traditional \& cultural leaders, the younger generation community. In fact, this research also found the strong role of supernatural groups consisting of shamans and charismatic clerics.

\section{REFERENCES}

[1] Bourdieu, P., (1986). The Form of Capital. In J. Richardson (Ed).Handbook of Theory and Research for Sosiology of Education. New York: Greenwood Press

[2] Creswell, W.John. (2017). Research Design: PendekatanMetodeKualitatif, Kuantitatif, dan Campuran. (Translator: AchmadFarawaid dan RianayatiKusminiPancasari). Yogyakarta: PustakaPelajar.

[3] Fatimah, Siti. (2018). Kampanyesebagai Komunikasi Politik. Resolusi: JurnalSosialPolitik, 1(1), 5-16.

[4] Field, John, (2018). Modal Sosial. (TerjemahanNurhadi). Bantul: KREASI WACANA.

[5] Fukuyama, Francis. (1999). The End of History and the Last Man: KemenanganKapitalisme dan Demokrasi Liberal. Yogyakarta: Penerbit Qalam

[6] --------. (2010). Trust, Kebajikan Sosial dan PenciptaanKemakmuran. (TerjemahanRuslani). Yogyakarta: Penerbit Qalam.

[7] Hartini, Wela dan Suprojo, Agung. (2016). Efektivitas Kinerja KepalaDesaDalamMewujudkanVisiMisi Pembangunan Des. Malang: JISIP: JurnalllmuSosial dan IlmuPolitik

[8] Ibrahim, Abd. Syukur. (1994). Panduan PenelitianEtnografi. Surabaya: Usaha Nasional.

[9] Kaplan, David dan Manners, A. Robert. (2012). TeoriBudaya. (TerjemahanL and ung Simatupang). Yogyakarta: Pustaka Pelajar.

[10] Miles, B. Matthte dan Huberman., A. Michaell., Saldana, Johnny. (2014). Quaitative Data Analysis. A. Methods Sourcebook, Edition 3. London: SAGE Publication, Inc.

[11] Nasrullah, Rulli. (2018). Etnografi Virtual. RisetKomunikasi, Budaya, dan Sosioteknologi di Internet. Bandung: SimbiosaRekatama Media.

[12] Richter. Jr, M.N. (1987). Exploring Sociology, Illinois: FE Peacock Publisher.

[13] Ritzer, George. (2015). TeoriSosiologi Modern. Edisiketujuh. (TerjemahanTriwibowo B.S.). Jakarta: PRENADAMEDIA GROUP.

[14] Soekanto, Soerjono dan Susityowati, Budi. (2017). SosiologiSuatuPengantar. Jakarta: PT. Raja GrafindoPersada.

[15] Syahra, Rusyidi. (2003). Modal sosial: Konsep dan aplikasi. Jurnal Masyarakat dan Budaya.

[16] Syamsudin, Zainal Abidin. (2008). Membongkar Dunia Klenik\&PerdukunanBerkedokKaromah, Jakarta: Pustaka Imam Abu Hanifah 
[17] Strauss, Anselm \& Corbin, Juliet. (2017). Dasar-dasarPenelitianKualitatif. Tatalangkah dan TeknikteknikTeoritisasi Data. Cetakan V. (Terjemahan Muhammad Shodiq\& Imam Muttaqien). Yogyakarta: Pustaka Pelajar.

Citation: Ishomuddin, et.al. "Social Capital in Achieving the Success of the Election of Mayors and Deputyof Palangka Raya" International Journal of Humanities Social Sciences and Education (IJHSSE), vol 7, no. 9, 2020, pp. 105-111. doi: https://doi.org/10.20431/2349-0381.0709010.

Copyright: (c) 2020 Authors. This is an open-access article distributed under the terms of the Creative Commons Attribution License, which permits unrestricted use, distribution, and reproduction in any medium, provided the original author and source are credited. 